\title{
BEZPIECZEŃSTWO MIĘDZYNARODOWE W TRAKTATACH O PRZYJAŹNI I WSPÓŁPRACY ZAWARTYCH PRZEZ POLSKĘ Z PAŃSTWAMI SĄSIEDNIMI
}

\section{Uwagi wstępne}

Wydarzenia w państwach Europy Środkowej i Wschodniej przełomu lat 1989-1990, które spowodowały transformację ustrojową oraz zmianę otoczenia międzynarodowego Polski i innych państw, wpłynęły na zmianę polskiej racji stanu ${ }^{1}$. Istotę tego stanu rzeczy oddał K. Skubiszewski, który w swym przemówieniu, wygłoszonym w dniu 21 stycznia 1993 r. podkreślił, że:

[...] racja stanu Polski nakazuje, aby w nadchodzących latach utwierdzać uzyskaną suwerenność, budować bezpieczeństwo państwa, wspierać gospodarczy i cywilizacyjny rozwój narodu i społeczeństwa oraz umacniać naszą pozycję na scenie międzynarodowej, zwłaszcza w Europie².

Kluczowym elementem tak ujmowanej racji stanu stało się zatem bezpieczeństwo Polski w nowych warunkach geopolitycznych ${ }^{3}$, co autor ten wyraził w słowach:

* Dr hab., Katolicki Uniwersytet Lubelski Jana Pawła II; e-mail: wojciech.staszewski@kul.lublin.pl, ORCID ID: https:/ / orcid.org/0000-0002-4139-3475.

1 Zob. K. Skubiszewski, Racja stanu Rzeczypospolitej Polskiej, [w:] K. Skubiszewski, Polityka zagraniczna i odzyskanie niepodległości. Przemówienia, oświadczenia, wywiady 1989-1993, Warszawa 1997, s. 301.

2 Tamże, s. 302.

3 Zob. J. Prystrom, Problem bezpieczeństwa w polityce zagranicznej Polski, [w:] B. Wizimirska (red.), Rocznik Polskiej Polityki Zagranicznej 1991, Warszawa 1993, s. 26 i nast. Na temat ówczesnej sytuacji i późniejszych uwarunkowań bezpieczeństwa Polski pisze: A.D. Rotfeld, Polska w niepewnym świecie, Warszawa 2006. Na temat geopolitycznych 
Podstawowym elementem naszej racji stanu jest bezpieczeństwo zewnętrzne. Rację stanu można wręcz sprowadzić do kwestii bezpieczeństwa. Bezpieczeństwo ma dwie strony: jedną zachowanie substancji państwa, drugą jest rozwój tej substancji. Można tu mówić o racji stanu gwarantującej nie tylko bezpieczeństwo, lecz także pewność i stabilność rozwoju4

To wzmocnienie gwarancji bezpieczeństwa Polski, jak trafnie zauważa E. Noworyta,

należało realizować poprzez zwiększenie własnego potencjału wojskowego i nowe powiązania sojusznicze. Pierwsze zadanie miało szansę realizacji w długiej perspektywie, drugie mogło zapewnić Polsce bezpieczeństwo niezwłocznie i stworzyć warunki dla pomyślnego dokończenia ustrojowej transformacji ${ }^{5}$.

Polska polityka zagraniczna stanęła przed zadaniem stworzenia odpowiednich gwarancji dla bezpieczeństwa Rzeczypospolitej Polskiej, co nie byłoby możliwe bez efektywnej polityki traktatowej państwa, stanowiącej jeden z elementów polityki zagranicznej in genere. Polityka traktatowa bowiem jest nie tylko miernikiem skuteczności prowadzonej przez państwo polityki zagranicznej ${ }^{6}$, ale - co wymaga szczególnego podkreślenia - tworzy trwałe gwarancje osiągania celów polityki zagranicznej danego państwa ${ }^{7}$. Zwrócił na to uwagę K. Skubiszewski w przemówieniu z 14 lutego 1991 r. twierdząc, że „szeroko pojęte bezpieczeństwo Polski i bezpieczeństwo w naszym regionie Europy trzeba budować od podstaw" ${ }^{8}$. Dodał, że

Sojusze dwustronne, sięgające swymi korzeniami lat czterdziestych, następnie Układ Warszawski z 1955 roku należą do minionej epoki. Likwidacja

konsekwencji wydarzeń przełomu lat 1989-1990 zob. też: R. Kuźniar, Polityka bezpieczeństwa w polskiej polityce zagranicznej, [w:] R. Kuźniar (red.), Polska polityka bezpieczeństwa 1989-2000, Warszawa 2001, s. 59 i nast.

4 K. Skubiszewski, Racja stanu Rzeczypospolitej Polskiej, s. 302.

5 E. Noworyta, Różne oblicza polskiej racji stanu, Łódź-Warszawa 2010, s. 91.

6 Zob. R. Podgórzańska, B. Szczepanik, Stowo wstępne, [w:] R. Podgórzańska, B. Szczepanik (oprac.), Uregulowania traktatowe Polski w latach 1945-1998: teksty wybranych dwustronnych umów politycznych zawartych przez Polskę z niektórymi krajami europejskimi, Koszalin 1999, s. 10.

7 Zob. J. Kukułka, Traktaty sąsiedzkie Polski Odrodzonej, Wrocław 1998, s. 6.

8 K. Skubiszewski, Problemy polityki zagranicznej u progu roku 1991 - wystapienie ministra spraw zagranicznych RP w Sejmie, Warszawa, 14 lutego 1991 r., "Zbiór Dokumentów" 1992, z. 1, s. 22. 
Układu Warszawskiego jest bliska. Dążymy do tego, aby wygasł on za zgodą wszystkich jego stron. Sojusze dwustronne na skutek swej treści, w znacznej mierze ideologicznej, przestały odpowiadać, podobnie zresztą jak Układ Warszawski, dzisiejszym okolicznościom. Będą one zastąpione nowymi układami ${ }^{9}$.

W nowej sytuacji geopolitycznej, realizując priorytety polskiej polityki zagranicznej, rozpoczął się okres budowy powiązań traktatowych ${ }^{10}$, które zapewniłyby gwarancje dla bezpieczeństwa państwa polskiego.

Ważne miejsce w stosunkach traktatowych państwa zajmują umowy o przyjaźni i współpracy (zwane traktatami politycznymi) ${ }^{11}$. Adam Banaszkiewicz pozwala sobie nawet na stwierdzenie, że są one „najważniejszymi porozumieniami pod względem znaczenia dla realizacji określonej polityki zagranicznej, jakie mogą zawrzeć ze sobą państwa" oraz dodaje, że stwarzają one „podstawy wzajemnych stosunków regulując główne kierunki współpracy i wyznaczając jej postacie instytucjonalne $[\ldots]^{\prime \prime} 12$.

Warto przy tym zauważyć, że zmiany w Europie Środkowej i Wschodniej spowodowały, iż zaszły poważne zmiany na granicach Polski - w istotny sposób zwiększyła się liczba jej sąsiadów. Wcześniej Polska graniczyła z trzema państwami, a obecnie z siedmioma.

Celem niniejszego opracowania jest udzielenie odpowiedzi na pytanie badawcze, czy w traktatach o przyjaźni i współpracy, zawartych przez Polskę po 1989 r. z państwami sąsiednimi, znalazły się postanowienia odnoszące się do bezpieczeństwa międzynarodowego, stanowiące przejaw wspólnego zainteresowania i współpracy państw w tym zakresie oraz czy regulacjom tym nadano odpowiednią rangę, a tym samym, czy w traktatach zawarto odpowiednie gwarancje zapewnienia bezpieczeństwa Rzeczypospolitej Polskiej.

9 Tamże, s. 22-23.

10 Zob. R. Szafarz, Stosunki traktatowe Rzeczypospolitej Polskiej. Nowa jakość w latach 1989-2000, „Studia Prawnicze” 2003, z. 2, s. 5.

11 Zob. A. Przyborowska-Klimczak, W.Sz. Staszewski, Wstęp, [w:] A. Przyborowska-Klimczak, W.Sz. Staszewski (oprac.), Traktaty o przyjaźni i wspótpracy zawarte przez Polskę. Wybór dokumentów, Lublin 2005, s. 5.

12 A. Banaszkiewicz, Umowy międzynarodowe jako środek osiagania celów w polityce zagranicznej państwa, [w:] M.S. Wolański (red.), Uwarunkowania i kierunki polskiej polityki zagranicznej w pierwszej dekadzie XXI wieku, Wrocław 2004, s. 35-36. 
Pierwszym państwem-sąsiadem, z którym Polska zawarła umowę o przyjaźni i współpracy była Republika Federalna Niemiec, co nastąpiło w dniu 17 czerwca 1991 r. ${ }^{13} \mathrm{~W}$ tym samym roku, w dniu 6 października 1991 r., podpisany został także traktat o przyjaźni i współpracy z ówczesną Czeską i Słowacką Republiką Federacyjną ${ }^{14}$. Umowa ta została podpisana jeszcze przed podziałem Czeskiej i Słowackiej Republiki Federacyjnej na dwa nowe państwa: Republikę Czeską i Republikę Słowacką ${ }^{15}$. Traktat ten obowiązuje nadal, gdyż oba powstałe państwa są jego sukcesorami ${ }^{16}$. W 1992 r. Polska podpisała traktaty przyjaźni z trzema sąsiadami: z Ukrainą

13 Traktat między Rzecząpospolitą Polską a Republiką Federalną Niemiec o dobrym sąsiedztwie i przyjaznej współpracy, podpisany w Bonn dnia 17 czerwca 1991 r., Dz. U. z 1992 r. Nr 14, poz. 56 oraz A. Przyborowska-Klimczak, W. Staszewski, Stosunki traktatowe Polski z państwami sąsiednimi. Wybór dokumentów, Lublin 1998, s. 21-33. Zgodnie z postanowieniami art. 38 ust. 2 traktatu wszedł on w życie dnia 16 stycznia 1992 r. (dalej: Traktat polsko-niemiecki z 1991 r.).

14 Układ między Rzecząpospolitą Polską a Czeską i Słowacką Republiką Federacyjną o dobrym sąsiedztwie, solidarności i przyjacielskiej współpracy, sporządzony w Krakowie dnia 6 października 1991 r., Dz. U. z 1992 r. Nr 59, poz. 296 oraz R. Podgórzańska, B. Szczepanik (oprac.), Uregulowania traktatowe Polski..., s. 148-156. Zgodnie z postanowieniami art. 23 ust. 1 układu wszedł on w życie w dniu 4 maja 1992 r. (dalej: Układ polsko-czechosłowacki z 1991 r.).

15 Zob. T.S. Szayna, Rozpad Czecho-Stowacji (kilka uwag o jego konsekwencjach), „Sprawy Międzynarodowe" 1993, z. 1, s. 55-59. Na temat przyczyn rozczłonkowania zob. R. Kochnowski, Geneza rozpadu Czechostowacji, „Studia Politicae Universitatis Silesiensis” 2005, t. 1, s. 154 i nast.; R. Zenderowski, Przyczyny rozpadu Czecho-Stowacji, „Sprawy Międzynarodowe" 2005, z. 3, s. 103 i nast.

16 Stosunki traktatowe z południowymi sąsiadami Polski uregulowały: Protokół między Rządem Rzeczypospolitej Polskiej a Rządem Republiki Czeskiej o sukcesji umów dwustronnych i przeglądzie systemu traktatowego między Rzecząpospolitą Polską i Republiką Czeską, podpisany w Warszawie w dniu 29 marca 1996 r. (wszedł w życie w dniu 23 sierpnia 1996 r.) oraz Protokół między Rządem Rzeczypospolitej Polskiej a Rządem Republiki Słowackiej dotyczący obowiązywania w stosunkach między Rzecząpospolitą Polską a Republiką Słowacką dwustronnych umów międzynarodowych zawartych między Polską (Rzecząpospolitą Polską, Polską Rzecząpospolitą Ludową) a Czechosłowacją (Republiką Czechosłowacką, Czechosłowacką Republiką Socjalistyczną, Czeską i Słowacką Republiką Federacyjną) w latach 1918-1992, podpisany w Bratysławie w dniu 8 lipca 1993 r. (wszedł w życie w dniu 6 czerwca 1994 r.); teksty obu porozumień w: A. Przyborowska-Klimczak, W. Staszewski, Stosunki traktatowe Polski..., s. 85-87, 117-119. Zob. A. Banaszkiewicz, Umowy międzynarodowe zawarte przez Polskę z państwami europejskimi w latach 1989-2000 jako środek realizacji polskiej polityki zagranicznej, Łódź 2007, s. 121. 
(18 marca 1992 r. ${ }^{17}$ ), Rosją (22 marca $1992 \mathrm{r}^{18}$ ) i Białorusią (23 czerwca $1992 \mathrm{r}^{19}{ }^{1}$ ). W 1994 r., po długich i trudnych negocjacjach ${ }^{20}$, został podpisany Traktat o przyjaźni i współpracy z ostatnim sąsiadem Polski - z Litwą w dniu 26 kwietnia 1994 r. $^{21}$

Przechodząc do analizy wspomnianych umów należy na wstępie zaznaczyć, że prawie wszystkie z nich zawierają postanowienia o potwierdzeniu istniejącej granicy oraz oświadczenia państw, że nie mają wobec siebie żadnych roszczeń terytorialnych oraz roszczeń takich nie będą wysuwać w przyszłości ${ }^{22}$. Wyjątek stanowi Traktat polsko-niemiecki, który został poprzedzony podpisanym w dniu 14 listopada 1990 r. Traktatem między Rzecząpospolitą Polską a Republiką Federalną Niemiec

17 Traktat między Rzecząpospolitą Polską a Ukrainą o dobrym sąsiedztwie, przyjaznych stosunkach i współpracy, sporządzony w Warszawie dnia 18 maja 1992 r., Dz. U. z 1993 r. Nr 125, poz. 573 oraz A. Przyborowska-Klimczak, W. Staszewski, Stosunki traktatowe Polski..., s. 120-126. Zgodnie z postanowieniami art. 21 ust. 1 traktatu wszedł on w życie w dniu 30 grudnia 1992 r. (dalej: Traktat polsko-ukraiński z 1992 r.).

18 Traktat między Rzecząpospolitą Polską a Federacją Rosyjską o przyjaznej i dobrosąsiedzkiej współpracy, sporządzony w Moskwie dnia 22 maja 1992 r., Dz. U. z 1993 r. Nr 61, poz. 291 oraz J. Kukułka, Traktaty sąsiedzkie Polski Odrodzonej, s. 226-231. Zgodnie z postanowieniami art. 21 ust. 1 traktatu wszedł on w życie w dniu 8 maja 1993 r. (dalej: Traktat polsko-rosyjski z 1992 r.).

19 Traktat między Rzecząpospolitą Polską a Republiką Białoruś o dobrym sąsiedztwie i przyjaznej współpracy, podpisany w Warszawie dnia 23 czerwca 1992 r., Dz. U. z 1993 r. $\mathrm{Nr}$ 118, poz. 527 oraz Z. Leszczyński, A. Koseski (red.), Stosunki międzynarodowe 1989-2000. Wybór tekstów źródtowych i materiatów, Pułtusk 2001, s. 209-214. Zgodnie z postanowieniami art. 27 traktatu wszedł on w życie w dniu 30 marca 1993 r. (dalej: Traktat polsko-białoruski z 1992 r.).

20 Poważnym problemem wzbudzającym kontrowersje podczas negocjacji była rozbieżna ocena historycznych stosunków polsko-litewskich. Na temat negocjacji zob.: L. Brodowski, Stosunki z Litwa, [w:] B. Wizimirska (red.), Rocznik Polskiej Polityki Zagranicznej 1995, Warszawa 1995, s. 115-116.; A. Chajewski, Okoliczności wynegocjowania i podpisania traktatu między Rzeczapospolita Polska a Republika Litewskg o przyjaznych stosunkach $i$ dobrosasiedzkiej wspótpracy, „Studium Vilnense A” 2017, t. 14, s. 98 i nast.

21 Traktat między Rzecząpospolitą Polską a Republiką Litewską o przyjaznych stosunkach i dobrosąsiedzkiej współpracy, sporządzony w Wilnie dnia 26 kwietnia 1994 r., Dz. U. z 1995 r. Nr 15, poz. 71 oraz A. Przyborowska-Klimczak, W. Staszewski, Stosunki traktatowe Polski..., s. 196-204. Zgodnie z postanowieniami art. 27 traktatu wszedł on w życie w dniu 26 listopada 1994 r. (dalej: Traktat polsko-litewski z 1994 r.).

22 Zob. art. 2 ust. 2 Układu polsko-czechosłowackiego z 1991 r.; art. 2 Traktatu polsko-ukraińskiego z 1992 r.; art. 2 Traktatu polsko-rosyjskiego z 1992 r.; art. 2 Traktatu polsko-białoruskiego z 1992 r.; art. 2 Traktatu polsko-litewskiego z 1994 r. 
o potwierdzeniu istniejącej między nimi granicy ${ }^{23}$. Warto przy tym zaznaczyć, że w preambule Traktatu polsko-niemieckiego z $1991 \mathrm{r}$. odniesiono się do umowy z 1990 r. $^{24}$

\section{Traktat polityczny z zachodnim sąsiadem Polski - z Niemcami}

W Traktacie polsko-niemieckim z 1991 r. państwa „przekonane o konieczności ostatecznego przezwyciężenia podziału w Europie oraz stworzenia sprawiedliwego i trwałego pokojowego ładu w Europie" ${ }^{25}$ uzgodniły, że będą kształtować swoje stosunki w duchu dobrego sąsiedztwa i przyjaźni oraz dążyć do ścisłej pokojowej i partnerskiej współpracy we wszystkich dziedzinach. Strony umowy stwierdziły także, że są świadome odpowiedzialności europejskiej i dołożą starań, aby urzeczywistnić pragnienie obu narodów osiągnięcia trwałego porozumienia i pojednania oraz że dążą do stworzenia Europy, w której przestrzegane są prawa człowieka i podstawowe wolności, a granice utracą dzielący charakter, również w wyniku przezwyciężania różnic gospodarczych i społecznych (art. 1). Państwa-strony zobowiązały się, że będą kierować się w kształtowaniu swych stosunków, a także w sprawach pokoju, bezpieczeństwa i współpracy w Europie i na świecie, przede wszystkim ośmioma zasadami, określonymi w art. 2 umowy. Pierwsza $\mathrm{z}$ nich stanowi, że nadrzędnym celem ich polityki jest zachowanie i umocnienie pokoju, a także zapobieganie wszelkim wojnom. Ponadto - kierując się pozostałymi zasadami - państwa-strony: postępują zgodnie z prawem międzynarodowym, w szczególności z postanowieniami Karty Narodów

23 Traktat między Rzecząpospolitą Polską a Republiką Federalną Niemiec o potwierdzeniu istniejącej między nimi granicy, podpisany w Warszawie dnia 14 listopada 1990 r., Dz. U. z 1992 r. Nr 14, poz. 54.

${ }^{24}$ Na temat obu traktatów pisze: R. Jasica, Polish-German Treaties of 1990 and 1991 on the Confirmation of Their Mutual Border and on Good Neighborliness and Friendly Co-operation, „Polish Yearbook of International Law” 1991, nr 1/2, s. 71 i nast. Zob. też: J. Barcz, Podstawy polityczne i prawne stosunków Polski ze zjednoczonymi Niemcami, [w:] B. Wizimirska (red.), Rocznik Polskiej Polityki Zagranicznej 1991, s. 60 i nast.; K. Gil, T. Jasułowski, Der Vertrag und die Folgen: Deutschland und Polen als Nachbarn, „Osteuropa” 2011, t. 61, nr 5/6, s. 49-55.

25 Preambuła Traktatu polsko-niemieckiego z $1991 \mathrm{r}$. 
Zjednoczonych z 1945 r. ${ }^{26}$, a także respektują postanowienia Aktu Końcowego Konferencji Bezpieczeństwa i Współpracy w Europie z 1975 r. ${ }^{27}$, Paryskiej Karty Nowej Europy z 1990 r. ${ }^{28}$ i innych dokumentów Konferencji Bezpieczeństwa i Współpracy w Europie (KBWE); przestrzegają wzajemnie suwerennej równości, integralności terytorialnej, nietykalności granic, niezawisłości politycznej oraz zasad zakazujących użycia siły lub groźby jej użycia; potwierdzają prawo wszystkich narodów i państw do swobodnego stanowienia o swym losie, bez zewnętrznej ingerencji oraz do kształtowania swego rozwoju politycznego, gospodarczego, społecznego i kulturalnego, według własnych życzeń; stawiają w centrum swej polityki człowieka z jego godnością i prawami oraz troską o przetrwanie ludzkości i zachowanie środowiska naturalnego; potępiają z całą stanowczością totalitaryzm, nienawiść rasową i etniczną, antysemityzm, ksenofobię i dyskryminację kogokolwiek, jak również prześladowanie z powodów religijnych i ideologicznych; uznają mniejszości i równorzędne grupy za naturalny pomost między narodami polskim i niemieckim oraz ufają, że te mniejszości i grupy wnoszą cenny wkład do życia ich społeczeństw. Wśród wyszczególnionych zasad znalazła się także - co wymaga podkreślenia - zasada, z której wynika, że strony potwierdzają bezpośrednie obowiązywanie powszechnych norm prawa międzynarodowego $\mathrm{w}$ prawie krajowym i w stosunkach międzynarodowych oraz są zdecydowane sumiennie wypełniać swe zobowiązania umowne, a także że będą we wszystkich dziedzinach urzeczywistniać Akt Końcowy KBWE, Paryską Kartę Nowej Europy oraz inne dokumenty KBWE.

Strony porozumienia nie tylko wyrzekły się użycia siły lub groźby jej użycia we wzajemnych stosunkach, ale również stosowania tego typu

26 Karta Narodów Zjednoczonych, podpisana podczas Konferencji Narodów Zjednoczonych w San Francisco dnia 26 czerwca 1945 r., Dz. U. z 1947 r. Nr 23, poz. 90 z późn. zm. oraz A. Przyborowska-Klimczak, Prawo międzynarodowe publiczne. Wybór dokumentów, Lublin 2006, s. 9-30 (dalej: Karta NZ).

27 Akt Końcowy Konferencji Bezpieczeństwa i Współpracy w Europie, przyjęty w Helsinkach w dniu 1 sierpnia 1975 r., tekst w: A.D. Rotfeld (red. i wprowadzenie), Z Lachowski, A.D. Rotfeld (wybór i oprac.), Od Helsinek do Madrytu. Dokumenty Konferencji Bezpieczeństwa $i$ Wspótpracy w Europie 1973-1983, Warszawa 1983, s. 110-203 (dalej: Akt Końcowy KBWE).

28 Paryska Karta Nowej Europy, przyjęta w Paryżu w dniu 21 listopada 1990 r., tekst w: A. Przyborowska-Klimczak, E. Skrzydło-Tefelska (oprac.), Dokumenty europejskie, t. 2, Lublin 1999, s. 78-91. 
instrumentów w jakikolwiek inny sposób niezgodny z celami i zasadami Karty NZ lub Aktu Końcowego KBWE. Uzgodniły, że będą rozstrzygać swe spory wyłącznie za pomocą środków pokojowych i zobowiązały się, iż nigdy nie użyją żadnych ze swych broni, chyba że dla indywidualnej albo zbiorowej samoobrony. Ponadto podkreśliły, że nigdy i w żadnych okolicznościach jako pierwsze nie skierują sił zbrojnych przeciw sobie (art. 5 ust. 1-3).

Strony zobowiązały się umacniać pokój poprzez tworzenie kooperacyjnych struktur bezpieczeństwa dla całej Europy i w związku z tym będą popierać $\mathrm{w}$ miarę możliwości, realizując $\mathrm{w}$ pełni postanowienia wynikające $\mathrm{z}$ dokumentów KBWE, proces bezpieczeństwa i współpracy w Europie oraz umacniać i rozwijać ten proces przy współudziale wszystkich państw uczestniczących w KBWE/OBWE (art. 5 ust. 4).

Kontrahenci określili też wspólny cel działania na rzecz umocnienia stabilności i zwiększenia bezpieczeństwa w Europie. Uzgodnili, że będą podejmować wspólne wysiłki w dziedzinie bezpieczeństwa, opowiadać się za redukcją „,sił zbrojnych i zbrojenia” do możliwie najniższego poziomu, umożliwiającego obronę, lecz nie dającego możliwości ataku, a także zobowiązali się wspólnie na rzecz rozszerzania środków budowy zaufania i stabilizacji, jak również innych politycznych środków kontroli zbrojeń, umacniających stabilność i zaufanie (art. 6) ${ }^{29}$.

W umowie uzgodniono także obowiązek niezwłocznego kontaktu w przypadku powstania sytuacji, która zdaniem jednej ze stron stanowi zagrożenie lub naruszenie pokoju, jak też „może wywołać niebezpieczne międzynarodowe powikłania". Kontrahenci - zgodnie z postanowieniami przedmiotowej umowy - mają starać się uzgodnić swe stanowiska oraz osiągnąć porozumienie do zastosowania właściwych środków, by poprawić lub opanować zaistniałą sytuację (art. 7).

Należy nadmienić, że w Traktacie polsko-niemieckim z 1991 r. uzgodniono, iż strony będą przeprowadzać regularne konsultacje, celem których jest zapewnienie rozwoju i pogłębiania wzajemnych stosunków, jak też uzgadnianie wspólnych stanowisk w sprawach międzynarodowych. Konsultacje szefów rządów będą odbywały się tak często, jak to będzie możliwe - nie rzadziej jednak niż raz $\mathrm{w}$ roku. Co najmniej raz $\mathrm{w}$ roku będą spotykali się ministrowie spraw zagranicznych obu państw, którzy

29 Zob. J. Barcz, Polska - Niemcy. Traktat o dobrym sąsiedztwie i przyjaznej wspótpracy, „Państwo i Prawo” 1991, z. 9, s. 29. 
zobowiązani zostali do sprawowania pieczy nad realizacją postanowień traktatu. Uzgodniono także kwestie regularnych kontaktów ministrów innych resortów, w tym także ministrów obrony narodowej, jak również zagadnienia dotyczące wspólnych komisji mieszanych (art. 3) ${ }^{30}$.

\section{Traktat polityczny z południowymi sąsiadami Polski - z Czechami i Słowacją}

Traktat podpisany przez Polskę z Czeską i Słowacką Republiką Federacyjną, który obecnie - o czym wspomniano wyżej - obowiązuje w stosunkach polsko-czeskich i polsko-słowackich, w preambule stanowi, że strony nawiązując do wielowiekowej tradycji przyjaźni, łączącej oba państwa i ich narody, potwierdzają „bezwzględne poszanowanie praw człowieka i jego podstawowych wolności, zasad demokracji i państwa praworządnego", jak również wyrażają "przekonanie, że ich przestrzeganie i konsekwentna realizacja stanowią fundament wolności, sprawiedliwości i pokoju". Kontrahenci zobowiązali się w stosunkach wzajemnych kierować się prawem międzynarodowym (art. 2 ust. 1$)^{31}$ oraz wszechstronnie wspierać utrzymanie i umocnienie bezpieczeństwa oraz rozwoju współpracy w Europie w celu stworzenia skutecznego ogólnoeuropejskiego systemu bezpieczeństwa, zwłaszcza bezpieczeństwa regionu, do którego przynależą (art. 4 ust. 1). Strony uzgodniły, że będą działać na rzecz umocnienia stabilizacji w Europie. Będą one - podobnie, jak ma to miejsce

30 Polska i Niemcy związane są także dwoma umowami dwustronnymi w zakresie współpracy wojskowej, a mianowicie: Umową między Rządem Rzeczypospolitej Polskiej a Rządem Republiki Federalnej Niemiec o czasowym pobycie członków sił zbrojnych Rzeczypospolitej Polskiej i członków sił zbrojnych Republiki Federalnej Niemiec na terytorium drugiego państwa, sporządzoną w Warszawie dnia 23 sierpnia $2000 \mathrm{r}$. (Dz. U. z 2002 r. Nr 206, poz. 1750) oraz Umową Ramową między Rządem Rzeczypospolitej Polskiej a Rządem Republiki Federalnej Niemiec o współpracy obronnej, podpisaną w Warszawie dnia 21 czerwca 2011 r. (M.P. z 2018 r. poz. 961).

31 Do kwestii przestrzegania prawa międzynarodowego nawiązano już w preambule traktatu słowami: „Rzeczpospolita Polska oraz Czeska i Słowacka Republika Federacyjna [...] przestrzegając prawa międzynarodowego, w szczególności Karty Narodów Zjednoczonych, działając zgodnie z Aktem Końcowym KBWE, Paryską Kartą Nowej Europy oraz innymi dokumentami Konferencji Bezpieczeństwa i Współpracy w Europie [...] uzgodniły, co następuje". 
w Traktacie polsko-niemieckim z 1991 r. - dążyć do osiągnięcia takiego stanu sił zbrojnych i uzbrojenia w Europie, aby został on zredukowany do poziomu odpowiedniego dla obrony, jednak uniemożliwiającego napaść, a także będą działać na rzecz umacniania zaufania (art. 4 ust. 2).

W Układzie polsko-czechosłowackim z 1991 r. państwa zobowiązały się, że w przypadku zbrojnej napaści na jedno z nich, porozumieją się $\mathrm{W}$ sprawie możliwości udzielenia napadniętemu pomocy, zgodnie z art. 51 Karty NZ ${ }^{32}$, jak również będą podejmować wysiłki, by konflikt został rozwiązany, zgodnie z zasadami określonymi w Karcie NZ i w dokumentach KBWE (art. 5 ust. 3).

Traktat zawiera także postanowienia, w których uregulowano zagadnienia dotyczące dwustronnych konsultacji. Uzgodniono, że kontrahenci będą organizować systematyczne konsultacje na różnych szczeblach w celu koordynacji stanowisk i działań w sprawach bezpieczeństwa i obrony. Ponadto, w przypadku powstania sytuacji międzynarodowej, która przez jednego z nich uznana zostanie za mogącą zagrozić lub naruszyć jego suwerenność, integralność terytorialną (w umowie użyto sformułowania: „całość terytorialną") lub inne żywotne interesy bezpieczeństwa, to wówczas obaj kontrahenci podejmą natychmiastowe konsultacje w sprawie najskuteczniejszego usunięcia zagrożenia. Przewidziano również, że strony będą podejmowały konsultacje w miarę potrzeby również i w innych przypadkach powstania lub trwania sporu lub sytuacji, jeżeli uznają, iż zostały zagrożone lub naruszone pokój i bezpieczeństwo międzynarodowe (art. 5).

Warto też dodać, że w umowie, wśród dziedzin współpracy, wyszczególniono współpracę w dziedzinie wojskowej (art. 6) ${ }^{33}$.

32 Artykuł 51 Karty NZ brzmi: „Nic w niniejszej Karcie nie narusza przyrodzonego prawa każdego członka Organizacji Narodów Zjednoczonych, przeciwko któremu dokonano zbrojnej napaści, do indywidualnej lub zbiorowej samoobrony, zanim Rada Bezpieczeństwa zastosuje środki konieczne utrzymania międzynarodowego pokoju i bezpieczeństwa. Członkowie, którzy zastosowali pewne środki w wykonywaniu swego prawa do samoobrony, natychmiast zawiadomią o tym Radę Bezpieczeństwa. Środki te w niczym nie naruszają opartego na niniejszej Karcie prawa i obowiązku Rady Bezpieczeństwa do podejmowania w każdym czasie akcji, jaką uzna ona za konieczną do utrzymania lub przywrócenia międzynarodowego pokoju i bezpieczeństwa".

33 Polska i Czechy są związane: Porozumieniem między Ministerstwem Obrony Narodowej Rzeczypospolitej Polskiej a Ministerstwem Obrony Republiki Czeskiej o współpracy w dziedzinie wojskowej, podpisanym w Vyszkovie w dniu 13 kwietnia 1996 r. (tekst w: Internetowa Baza Traktatowa MSZ, https://traktaty.msz.gov.pl/ [dostęp: 10.05.2019 r.]) 


\section{Traktaty polityczne ze wschodnimi sąsiadami Polski - z Ukrainą, Rosją, Białorusią i Litwą}

\subsection{Traktat polsko-ukraiński}

W preambule Traktatu polsko-ukraińskiego z 1992 r. o przyjaźni i współpracy strony podkreśliły, że są „świadome swojej współodpowiedzialności za pokój, bezpieczeństwo, porozumienie i współpracę na kontynencie europejskim, w tym w Europie Środkowej" oraz potwierdziły poszanowanie praw człowieka i podstawowych wolności, zasad demokracji i sprawiedliwości, a także stwierdziły, że uzgodniły go „pragnąc wnieść wkład w budowę sprawiedliwego i pokojowego ładu europejskiego, opartego na ogólnoeuropejskich normach i mechanizmach w dziedzinie bezpieczeństwa” oraz „przestrzegając celów i zasad Karty Narodów Zjednoczonych, Aktu Końcowego Konferencji Bezpieczeństwa i Współpracy w Europie, Paryskiej Karty dla Nowej Europy oraz innych dokumentów współpracy europejskiej".

Przechodząc do analizy postanowień dotyczących kwestii bezpieczeństwa należy zauważyć, że w art. 1 traktatu, kontrahenci wyeksponowali swoje zobowiązanie do rozwijania stosunków w duchu przyjaźni, współpracy, wzajemnego szacunku, zrozumienia, zaufania i dobrego sąsiedztwa na podstawie prawa międzynarodowego, $w$ tym zasad suwerennej równości, niestosowania siły lub groźby jej użycia, nienaruszalności granic, integralności terytorialnej, pokojowego załatwiania sporów, nieingerencji w sprawy wewnętrzne, samostanowienia narodów, poszanowania praw człowieka i podstawowych wolności, wykonania w dobrej wierze zobowiązań wynikających z prawa międzynarodowego. Dodatkowo $\mathrm{w}$ art. 4 ust. 1 traktatu znalazło się postanowienie, w którym strony podkreśliły, że będą rozstrzygać spory, które mogłyby powstać między nimi, wyłącznie środkami pokojowymi oraz wyrzekają się użycia siły lub groźby jej użycia w stosunkach wzajemnych.

oraz Porozumieniem między Ministerstwem Obrony Narodowej Rzeczypospolitej Polskiej a ministerstwem Obrony Republiki Czeskiej w sprawie ochrony wojskowych informacji niejawnych, podpisanym w Sychrovie w dniu 1 października 1998 r. (tekst w: Internetowa Baza Traktatowa MSZ, https:/ / traktaty.msz.gov.pl/ [dostęp: 10.05.2019 r.]). Polska i Słowacja związane są Umową między Rządem Rzeczypospolitej Polskiej a Rządem Republiki Słowackiej o współpracy obronnej, podpisaną w Bratysławie dnia 16 maja 2014 r. (M.P. z 2017 r. poz. 240). 
Państwa-strony umowy zobowiązały się - w celu umocnienia bezpieczeństwa, zaufania, stabilności i współpracy - że będą aktywnie współdziałać w odpowiednich europejskich mechanizmach i strukturach, na podstawie Aktu Końcowego KBWE, Paryskiej Karty Nowej Europy, Traktatu o konwencjonalnych siłach zbrojnych w Europie ${ }^{34}$, Układu o nierozprzestrzenianiu broni jądrowej ${ }^{35}$ oraz innych międzynarodowych porozumień $\mathrm{w}$ dziedzinie rozbrojenia ${ }^{36}$. Będą one także współpracować na rzecz bezpieczeństwa i stabilności w Europie, ze szczególnym uwzględnieniem bezpieczeństwa regionalnego. $W$ tym celu, będą wspierać proces rozbrojenia $\mathrm{w}$ dziedzinie broni jądrowej, chemicznej i innych rodzajów broni masowej zagłady oraz broni konwencjonalnej. Strony przyjęły również na siebie zobowiązanie, że w celu zapobiegania rozprzestrzenianiu broni masowej zagłady w świecie, a zwłaszcza w Europie, wyrzekają się posiadania, nabywania i wytwarzania takiej broni. Zagwarantowały także pełną kontrolę wytwarzania i przechowywania na swoich terytoriach materiałów i substancji, które służą celom pokojowym, lecz mogą być wykorzystane do produkcji broni masowej zagłady, jak również zastrzegły

34 Traktat o konwencjonalnych siłach zbrojnych w Europie, podpisany w Paryżu dnia 19 listopada 1990 r., Dz. U. z 1995 r. Nr 15, poz. 73, zał. Na temat postanowień traktatu zob.: T. Kapuśniak, Struktura reżimu o rozbrojeniu konwencjonalnym w Europie, „Annales Universitatis Mariae Curie-Skłodowska" Sectio K Politologia 2005, t. 12, s. 75 i nast. Zob. też: M. Mróz, Traktat o konwencjonalnych siłach zbrojnych w Europie (CFE) (wersja poprawiona, uzupetniona i zaktualizowana), „Raport Biura Studiów i Analiz Kancelarii Sejmu” 2015, nr 74A.

35 Układ o nierozprzestrzenianiu broni jądrowej, sporządzony w Moskwie, Waszyngtonie i Londynie dnia 1 lipca 1968 r., Dz. U. z 1970 r. Nr 8, poz. 60, zał. Na temat Układu zob.: T. Gadkowski, Międzynarodowa kontrola nierozprzestrzeniania broni jądrowej, „Ruch Prawniczy, Ekonomiczny i Socjologiczny" 1983, z. 4, s. 97 i nast. Zob. też: R. Kopeć, Traktat o nierozprzestrzenianiu broni nuklearnej jako prawnomiędzynarodowy reżim zapobiegania proliferacji, "Annales Universitatis Paedagogicae Cracoviensis. Studia de Securitate et Educatione Civili" 2015, nr 5, s. 86 i nast.

36 Zob. T.Strulak, Działania na rzecz rozbrojenia i kontroli zbrojeń, [w:] J.Symonides (red.), Organizacja Narodów Zjednoczonych. Bilans i perspektywy, Warszawa 2006, s. 161 i nast.; M. Kaczmarski, Problematyka zbrojeń i rozbrojenia, [w:] R. Zięba (red.), Bezpieczeństwo międzynarodowe po zimnej wojnie, Warszawa 2008, s. 520 i nast.; M. Tabor, Porozumienia w sprawie kontroli zbrojeń i rozbrojenia, [w:] R. Kuźniar i in., Bezpieczeństwo międzynarodowe, Warszawa 2012, s. 143 i nast. Zob. też: Z. Cesarz, Kwestia zbrojeń i rozbrojenia, [w:] Z. Cesarz, E. Stadtmüller, Problemy polityczne wspótczesnego świata, Wrocław 2000, s. 105 i nast.; tenże, Problemy rozbrojenia i ograniczenia zbrojen, [w:] T. Łoś-Nowak (red.), Wspótczesne stosunki międzynarodowe, Wrocław 1995, s. 142 i nast. 
pełną kontrolę eksportu tych materiałów i substancji oraz technologii służących ich wytwarzaniu (art. 3) $)^{37}$.

Zgodnie $\mathrm{z}$ art. 4 ust. 2 umowy żadna ze stron nie pozwoli, aby $\mathrm{z}$ jej terytorium państwo trzecie lub państwa trzecie dokonały aktu agresji zbrojnej przeciwko drugiemu kontrahentowi. Natomiast w sytuacji, gdy państwo trzecie lub państwa trzecie dokonają zbrojnej napaści na jednego z kontrahentów, to drugi nie będzie udzielał jakiejkolwiek pomocy militarnej i poparcia politycznego takiemu państwu lub takim państwom, przez cały czas trwania konfliktu zbrojnego oraz będzie działać na rzecz uregulowania tego konfliktu, zgodnie $\mathrm{z}$ zasadami i procedurą, przewidzianą w postanowieniach Karty NZ i dokumentach KBWE (art. 4 ust. 3).

$\mathrm{W}$ porozumieniu - w dwóch różnych miejscach - uzgodniono zagadnienia dotyczące konsultacji umawiających się państw. Przewidziano, w art. 4 ust. 4 traktatu, że będą przeprowadzane konsultacje w sprawach bezpieczeństwa międzynarodowego na wszystkich szczeblach. Dodano, że w sytuacji, kiedy jedna ze stron umowy uzna, iż powstała sytuacja lub spór, który zagraża lub może zagrażać utrzymaniu międzynarodowego pokoju i bezpieczeństwa albo je narusza, to wówczas kontrahenci przeprowadzą niezwłoczne konsultacje, dotyczące sposobów uregulowania sporu lub położenia kresu powstałej sytuacji. Ponadto w art. 6 ust. 1 postanowiono, że umawiające się państwa będą odbywać konsultacje na różnych szczeblach (w tym najwyższym), których celem jest zapewnienie harmonijnego rozwoju wzajemnych stosunków, jak również współpracy w sprawach o charakterze wielostronnym, stanowiącym przedmiot wspólnego zainteresowania, ze szczególnym uwzględnieniem problemów bezpieczeństwa międzynarodowego.

Warto też dodać, że państwa zgodziły się działać, w celu umacniania i dalszej instytucjonalizacji Konferencji Bezpieczeństwa i Współpracy w Europie oraz innych struktur ogólnoeuropejskich, na rzecz współpracy politycznej, gospodarczej, ekologicznej, kulturalnej, naukowej, humanitarnej i prawnej, zwłaszcza współtworzenia, rozwijania i upowszechniania ogólnoeuropejskich standardów w tych dziedzinach (art. 5).

37 Należy podkreślić, że Ukraina przekazała cały posiadany arsenał jądrowy Rosji w zamian za gwarancje bezpieczeństwa, które zostały udzielone przez Stany Zjednoczone Ameryki, Federację Rosyjską i Zjednoczone Królestwo Wielkiej Brytanii i Irlandii Północnej w dniu 5 grudnia 1994 r., zob. M. Żyła, Między Wschodem a Zachodem. Problemy bezpieczeństwa militarnego Ukrainy, "Ante Portas - Studia nad Bezpieczeństwem” 2016, nr 1, s. 254. 
Należy też zauważyć, że w Traktacie polsko-ukraińskim z 1992 r. - podobnie, jak w umowie zawartej przez Polskę z ówczesną Czeską i Słowacką Republiką Federacyjną - wśród dziedzin współpracy wyszczególniono też współpracę w dziedzinie wojskowej (art. 4 ust. 5) 38. $^{38}$

\subsection{Traktat polsko-rosyjski}

W Traktacie polsko-rosyjskim z $1992 \mathrm{r}$. w preambule strony podkreśliły, że zawierając go kierują się celami i zasadami Karty NZ oraz potwierdziły zasady wyrażone w Akcie Końcowym KBWE, Paryskiej Karcie Nowej Europy oraz w pozostałych dokumentach KBWE i innych dokumentach współpracy ogólnoeuropejskiej. Zaznaczyły również, iż pragną wnieść wkład w budowę pokojowego ładu europejskiego, opartego na

38 Strony związały się: Porozumieniem między Rządem Rzeczypospolitej Polskiej a Rządem Ukrainy o wzajemnych dostawach uzbrojenia, techniki wojskowej i świadczeniu usług o charakterze wojskowo-technicznym, sporządzonym w Kijowie w dniu 10 października 1996 r. (tekst w: Internetowa Baza Traktatowa MSZ, https://traktaty.msz.gov. pl/ [dostęp: 10.05.2019 r.]); Protokołem między Rządem Rzeczypospolitej Polskiej a Gabinetem Ministrów Ukrainy w sprawie wprowadzenia zmian do Porozumienia między Rządem Rzeczypospolitej Polskiej a Rządem Ukrainy o wzajemnych dostawach uzbrojenia, techniki wojskowej i świadczenia usług o charakterze wojskowo-technicznym, sporządzonego w Kijowie dnia 10 października 1996 r., sporządzonym w Warszawie w dniu 9 lipca 2016 r. (tekst w: Internetowa Baza Traktatowa MSZ, https:/ / traktaty.msz.gov.pl/ [dostęp: 10.05.2019 r.]) oraz Protokołem między Ministrem Obrony Narodowej Rzeczypospolitej Polskiej a Ministerstwem Obrony Ukrainy o nieodpłatnym przekazaniu wybranych składników mienia wojskowego, podpisanym w Warszawie dnia 14 sierpnia 2014 r. (M.P. z 2015 r. poz. 581). Polska i Ukraina są stronami także: Umowy między Rządem Rzeczypospolitej Polskiej a Gabinetem Ministrów Ukrainy o dodatkowych środkach budowy zaufania i bezpieczeństwa, podpisanej w Warszawie dnia 16 kwietnia 2004 r. (M.P. z 2005 r. Nr 5, poz. 47) oraz Umowy Ogólnej między Rządem Rzeczypospolitej Polskiej a Gabinetem Ministrów Ukrainy w sprawie wzajemnej współpracy w dziedzinie obronności, sporządzonej w Warszawie dnia 2 grudnia 2016 r. (M.P. z 2019 r. poz. 50). Zob. M. Żyła, Polsko-ukraińska wspótpraca wojskowa w polityce bezpieczeństwa Polski, Warszawa 2016 (szczególnie rozdziały 2 i 3 ).

Dokonując analizy Traktatu polsko-ukraińskiego z 1992 r. godzi się też zauważyć, że w postanowieniach odnoszących się do współpracy w zakresie ochrony środowiska naturalnego użyto sformułowania „bezpieczeństwo ekologiczne”. Szerzej na ten temat zob. W.Sz. Staszewski, Wspótpraca w zakresie ochrony środowiska w traktatach o przyjaźni i wspótpracy zawartych przez Polske po 1989 r., [w:] B. Mikołajczyk, J. Nowakowska-Małusecka (red.), Prawo międzynarodowe, europejskie i krajowe - granice $i$ wspólne obszary. Księga jubileuszowa dedykowana Profesor Genowefie Grabowskiej, Katowice 2009, s. 547-548. 
samostanowieniu narodów, demokracji i sprawiedliwości, zapewnieniu praw i podstawowych wolności człowieka.

Państwa zobowiązały się kształtować swoje stosunki w duchu przyjaźni, dobrosąsiedzkiego partnerstwa, równouprawnienia, zaufania i wzajemnego szacunku, opierając się na prymacie prawa międzynarodowego i na zasadach poszanowania suwerenności, nienaruszalności granic, integralności terytorialnej, nieingerencji w sprawy wewnętrzne oraz prawa narodów do samostanowienia (art. 1). Kontrahenci zapewnili, że będą rozwiązywać swoje spory wyłącznie środkami pokojowymi, a także, iż będą powstrzymywać się od użycia siły i groźby jej użycia we wzajemnych stosunkach (art. 3 ust. 1).

Strony uzgodniły, że będą - stosowanie do postanowień odpowiednich dokumentów KBWE - współdziałać w celu utrzymania i umocnienia bezpieczeństwa na kontynencie europejskim. Będą wprowadzać w życie uzgodnione ogólnoeuropejskie środki umacniania zaufania i bezpieczeństwa, a także ustalą dodatkowe - w razie potrzeby - środki tego rodzaju. Kontrahenci podkreślili, że poświęcą szczególną uwagę sprawom umocnienia bezpieczeństwa oraz środkom zaufania w rejonie Morza Bałtyckiego (art. 4).

Umawiające się państwa postanowiły, że będą aktywnie wspierać proces rozbrojenia jądrowego, chemicznego i biologicznego. Podejmą, zgodnie z postanowieniami Układu o nierozprzestrzenianiu broni jądrowej, działania na rzecz zapobiegania rozprzestrzenianiu tej broni w świecie, a w szczególności w Europie Środkowej i Wschodniej. Wyraziły również stanowisko, że redukcja zbrojeń do stopnia wystarczającego do obrony oraz wykonywanie Traktatu o konwencjonalnych siłach zbrojnych w Europie, prowadzą do utrwalenia stabilizacji i bezpieczeństwa w Europie. Partnerzy umowy przyjęli na siebie zobowiązanie, z którego wynika, że podejmą środki w celu zagwarantowania eksportu towarów i technologii, które służą celom pokojowym, lecz mogą być wykorzystane do produkcji broni masowej zagłady (art. 5 ust. 1-3) ${ }^{39}$.

39 Strony związały się Umową między Rządem Rzeczypospolitej Polskiej a Rządem Federacji Rosyjskiej dotyczącą współpracy przy wwozie do Federacji Rosyjskiej napromieniowanego paliwa jądrowego z reaktora doświadczalnego, sporządzoną w Sopocie w dniu 1 września 2009 r., tekst w: Internetowa Baza Traktatowa MSZ, https:/ / traktaty. msz.gov.pl/ [dostęp: 10.05.2019 r.]. 
Bardzo istotne $\mathrm{w}$ przedmiotowej materii postanowienia znalazły się w art. 3 ust. 2 i 3 traktatu. Przewidziano, że żadna ze stron nie dopuści, aby $z$ jego terytorium państwo trzecie lub państwa trzecie dokonały aktu zbrojnej agresji przeciwko drugiej stronie. Każdy z kontrahentów zagwarantował także, że działalność jego sił zbrojnych na jego terytorium będzie zgodna z postanowieniami Karty NZ, Aktu Końcowego KBWE, Paryskiej Karty Nowej Europy oraz innych dokumentów KBWE.

$\mathrm{W}$ art. 7 traktatu strony uregulowały zagadnienia rozwijania wspólnych kontaktów. Jednocześnie uznały za konieczne przeprowadzenie niezwłocznych konsultacji, w przypadku powstania sporu lub sytuacji, które, zdaniem jednej z nich, mogą zagrażać lub zagrażają utrzymaniu pokoju międzynarodowego lub bezpieczeństwa albo naruszają pokój międzynarodowy lub bezpieczeństwo, a w szczególności, gdy taki spór lub sytuacja dotyczą bezpieczeństwa obu kontrahentów. Celem konsultacji ma być poszukiwanie możliwych środków pokojowego uregulowania sporu lub powstałej sytuacji, zgodnie z postanowieniami Karty NZ (art. 6 ust. 1).

Kontrahenci ustalili, że w przypadku zaistnienia sytuacji, w której państwo trzecie lub państwa trzecie, dokonały zbrojnej napaści na jednego z nich, drugi zobowiązuje się nie udzielać jakiejkolwiek pomocy i poparcia takiemu państwu lub państwom przez cały czas trwania konfliktu zbrojnego oraz będzie podejmować działania na rzecz uregulowania tego konfliktu, zgodnie z Kartą NZ z 1945 r. oraz z dokumentami KBWE (art. 6 ust. 2).

W omawianym Traktacie polsko-rosyjskim z 1992 r. uwzględniono także możliwość współpracy wojskowej ${ }^{40}$.

\subsection{Traktat polsko-białoruski}

Traktat polsko-białoruski z 1992 r. w preambule odnosi się - tak jak poprzednie traktaty - do celów i zasad Karty NZ, ale również Aktu Końcowego KBWE, Paryskiej Karty Nowej Europy, jak też i innych dokumentów

40 Kontrahenci związali się Porozumieniem między Rządem Rzeczypospolitej Polskiej a Rządem Federacji Rosyjskiej w sprawie współpracy wojskowo-technicznej, podpisanym w Moskwie dnia 22 kwietnia 2003 r., Dz. U. z 2004 r. Nr 216, poz. 2199.

Należy też dodać, że użyto również, podobnie jak to ma miejsce w umowie polsko-ukraińskiej, w zakresie postanowień dotyczących współpracy w zakresie ochrony środowiska naturalnego określenia „bezpieczeństwo ekologiczne”. Szerzej na ten temat zob. W.Sz. Staszewski, Wspótpraca w zakresie ochrony środowiska..., s. 548. 
współpracy europejskiej. Strony zaakcentowały, że są świadome swej odpowiedzialności za pokój i bezpieczeństwo w świecie oraz pragną wnieść wkład w budowę sprawiedliwego i pokojowego ładu w Europie, a także potwierdziły swoje poszanowanie praw człowieka oraz podstawowych wolności, zasad demokracji, sprawiedliwości, a także tolerancji, stanowiących niezbywalny element dziedzictwa europejskiego.

Strony zobowiązały się kształtować swoje stosunki jako zaprzyjaźnione państwa, w duchu wzajemnego szacunku, dobrosąsiedztwa i partnerstwa. Mają się kierować przy tym zasadami suwerennej równości, niestosowania siły lub groźby jej użycia, nienaruszalności granic, integralności terytorialnej, pokojowego rozstrzygania sporów, nieingerencji w sprawy wewnętrzne, poszanowania praw człowieka i podstawowych swobód oraz prawa narodów do samostanowienia (art. 1). Dodatkowo w art. 6 porozumienia kontrahenci podkreślili, że będą rozstrzygać spory, mogące między nimi powstać, zgodnie z postanowieniami Karty NZ i odpowiednimi dokumentami KBWE, wyłącznie środkami pokojowymi.

Uzgodniono, że partnerzy umowy zobowiązują się umacniać europejskie mechanizmy bezpieczeństwa, stabilności i współpracy na podstawie Aktu Końcowego KBWE, Paryskiej Karty Nowej Europy, innych dokumentów KBWE, a także Traktatu o konwencjonalnych siłach w Europie (art. 3). Będą oni zarówno wspierać proces rozbrojenia w dziedzinie broni jądrowej, chemicznej i innych rodzajów broni masowego rażenia oraz broni konwencjonalnej, jak też zmierzać do dalszego ograniczenia sił zbrojnych i zbrojeń w Europie do stopnia wystarczającego do obrony, a także umacniać środki budowy zaufania i bezpieczeństwa w sferze militarnej (art. 4).

W Traktacie polsko-białoruskim z 1992 r. strony odwołały się do postanowień Układu o nierozprzestrzenianiu broni jądrowej i powzięły decyzję, że będą współpracować na rzecz nierozprzestrzeniania tej broni, w szczególności w Europie Środkowej i Wschodniej, a także podejmą współpracę, celem zagwarantowania kontroli eksportu towarów i technologii, które służą celom pokojowym, ale mogą być wykorzystywane do produkcji broni masowej zagłady (art. 5).

Kontrahenci, co należy wyraźnie podkreślić, wyrzekli się użycia siły lub groźby jej użycia we wzajemnych stosunkach. Zobowiązali się, że nie pozwolą, aby ich terytoria były wykorzystywane przez państwo trzecie lub państwa trzecie w celach zbrojnej agresji lub wrogiej działalności przeciwko drugiemu kontrahentowi. W porozumieniu przewidziano także, że w sytuacji dokonania napaści przez państwo trzecie lub państwa trzecie na 
jedną ze stron umowy, ta druga zobowiązuje się do nieudzielania pomocy militarnej ani jakiegokolwiek poparcia takiemu państwu lub państwom przez cały czas trwania konfliktu zbrojnego, a także podejmie działania na rzecz uregulowania tego konfliktu, zgodnie z zasadami ujętymi w Karcie NZ i dokumentami KBWE. Zaakcentowano również, że zobowiązania te nie naruszają praw i obowiązków kontrahentów, które wynikają z postanowień Karty NZ (art. 7).

W umowie przyjęto też regulacje w zakresie spotkań i konsultacji na różnym szczeblu między organami władzy i administracji państwowej (art. 10), ale także, co wymaga zaakcentowania, uzgodniono kwestie przeprowadzania konsultacji w sprawach bezpieczeństwa międzynarodowego. W sytuacji, kiedy jeden z kontrahentów uzna, że powstała sytuacja lub konflikt zagrażający pokojowi międzynarodowemu lub europejskiemu bądź naruszający to bezpieczeństwo, to wówczas partnerzy umowy przeprowadzą bezzwłoczne konsultacje na temat możliwych sposobów przezwyciężenia zaistniałej sytuacji lub uregulowania konfliktu. Jak ustalono $\mathrm{w}$ porozumieniu - będzie to prowadzone zgodnie $\mathrm{z}$ dokumentami KBWE (art. 8).

Co ciekawe, w umowie przewidziano, że umawiające się państwa będą - $\mathrm{w}$ razie potrzeby - przeprowadzać konsultacje $\mathrm{w}$ dziedzinie obrony w sprawach będących przedmiotem ich wspólnego zainteresowania (art. 9).

Należy też zauważyć, że w Traktacie polsko-białoruskim z 1992 r., wśród dziedzin priorytetowych, nie wyszczególniono współpracy wojskowej ${ }^{41}$.

\subsection{Traktat polsko-litewski}

W ostatniej z analizowanych umów, tj. w Traktacie polsko-litewskim z 1994 r., strony podkreśliły w preambule, że kierują się celami i zasadami Karty NZ, Aktu Końcowego KBWE, Paryskiej Karty Nowej Europy oraz dokumentów wielostronnej współpracy ogólnoeuropejskiej oraz dążą do wszechstronnego rozwoju wzajemnych stosunków i przyjaznej współpracy, w oparciu o zasadę dobrosąsiedztwa. Jednocześnie państwa stwierdziły, że uzgodniły umowę „dążąc do wniesienia swego wkładu do procesu

41 Dodać wypada, że w postanowieniach dotyczących ochrony środowiska naturalnego użyto sformułowania „bezpieczeństwo i współpraca ekologiczna”. Szerzej na ten temat zob. W.Sz. Staszewski, Wspótpraca w zakresie ochrony środowiska..., s. 548-549. 
integracji Europy i świadome wspólnoty ich interesów oraz swojej współodpowiedzialności za pokój, bezpieczeństwo, porozumienie i współpracę w demokratycznej, wolnej i szanującej prawa człowieka Europie" oraz „deklarując wolę współdziałania na płaszczyźnie dwustronnej, jak i w ramach organizacji i instytucji międzynarodowych, jak również w celu rozwoju wszechstronnej współpracy w regionie bałtyckim".

Kontrahenci wskazali, że będą kształtować swoje stosunki w duchu wzajemnego szacunku, zaufania, równouprawnienia i dobrosąsiedztwa, a także - co wymaga podkreślenia - w poszanowaniu prymatu prawa międzynarodowego, a w szczególności zasad poszanowania suwerenności, nienaruszalności granic, zakazu agresji zbrojnej, integralności terytorialnej w sprawy wewnętrzne oraz przestrzegania praw człowieka i podstawowych wolności (art. 1). Zobowiązali się rozwiązywać swoje spory tylko przy wykorzystaniu środków pokojowych (zgodnie z Kartą NZ oraz odpowiednimi dokumentami KBWE), a także zagwarantowali, że powstrzymają się w stosunkach wzajemnych od użycia siły i groźby jej użycia (art. 3 ust. 1). Umawiające się państwa stwierdziły, że zobowiązują się do bezwzględnego poszanowania ich suwerenności i integralności terytorialnej (art. 2 ust. 1).

Strony zgodziły się w porozumieniu, że będą, stosownie do odpowiednich dokumentów KBWE, współdziałać w celu utrzymania i umocnienia bezpieczeństwa na kontynencie europejskim. Będą także wprowadzać $\mathrm{w}$ życie uzgodnione europejskie środki umacniania zaufania i bezpieczeństwa, a w razie potrzeby uzgodnią dodatkowe tego rodzaju środki. Podkreśliły, że szczególną uwagę poświęcą sprawom umocnienia bezpieczeństwa oraz środkom zaufania w regionie Morza Bałtyckiego (art. 4). Dodatkowo w art. 7 umowy stwierdzono, że kontrahenci będą tworzyć, w ramach Rady Państw Morza Bałtyckiego ${ }^{42}$ i innych organizacji oraz instytucji regionu bałtyckiego, sprzyjające warunki dla rozwoju współpracy i dobrego sąsiedztwa w tej części Europy ${ }^{43}$.

Partnerzy umowy ustalili, że będą aktywnie wspierać proces rozbrojenia jądrowego, chemicznego i biologicznego. Będą oni współdziałać,

42 Na temat charakterystyki regionu i Rady Państw Morza Bałtyckiego zob. I. Śmigerska-Belczak, Wspótpraca w regionie Morza Battyckiego - Rada Państw Morza Bałtyckiego, „Kwartalnik Kolegium Ekonomiczno-Społecznego. Studia i Prace” 2012, nr 1, s. 175 i nast.

43 Na temat współpracy obronnej w regionie Morza Bałtyckiego zob. P. Pacuła, Wspótpraca obronna w regionie Morza Bałtyckiego. Stan obecny i perspektywy, „Bezpieczeństwo Narodowe" 2013, t. 26, nr 2, s. 51 i nast. 
zgodnie z postanowieniami Układu o nierozprzestrzenianiu broni jądrowej, na rzecz zapobiegania rozprzestrzenianiu broni jądrowej w świecie, a w szczególności w Europie Środkowej i Wschodniej. Zgodzili się także podejmować środki w celu zagwarantowania kontroli eksportu towarów i technologii, które służą celom pokojowym, ale mogą być wykorzystane do produkcji broni masowej zagłady. Partnerzy umowy zawarli też w porozumieniu wspólne stanowisko, że uważają, iż redukcja zbrojeń do poziomu niezbędnej wystarczalności do obrony oraz wykonywanie Traktatu o konwencjonalnych siłach zbrojnych w Europie będą prowadziły do utrwalania stabilności i bezpieczeństwa w Europie (art. 5 ust. 1-3).

W Traktacie polsko-litewskim z 1994 r. strony zobowiązały się, że żadna z nich nie dopuści, aby z jej terytorium państwo trzecie lub państwa trzecie dokonały aktu agresji przeciw drugiej z umawiających się stron (art. 3 ust. 2). Natomiast, gdyby państwo trzecie lub państwa trzecie dokonały zbrojnej napaści na jedną z nich, to druga strona nie będzie udzielać jakiejkolwiek pomocy i poparcia takiemu państwu lub państwom przez cały czas trwania konfliktu zbrojnego oraz będzie działać na rzecz uregulowania tego konfliktu, zgodnie z Kartą NZ i dokumentami KBWE (art. 6 ust. 2).

Umowa zawiera również postanowienia regulujące zagadnienia wzajemnych spotkań i konsultacji władz państwowych różnego szczebla (art. 8), a także przewidujące, że w przypadku powstania sporu lub sytuacji, które zdaniem jednego z kontrahentów mogą zagrażać lub zagrażają utrzymaniu pokoju lub bezpieczeństwa w świecie albo naruszają pokój międzynarodowy lub bezpieczeństwo, a w szczególności, gdy taki spór lub sytuacja dotyczy obu państw, to wówczas strony niezwłocznie przeprowadzą stosowne konsultacje, w celu poszukiwania możliwych środków uregulowania sporu lub powstałej sytuacji, zgodnie z Kartą NZ (art. 6 ust. 1).

Należy też zauważyć, że każda ze stron Traktatu polsko-litewskiego z 1994 r. zagwarantowała, że działalność sił zbrojnych na jej terytorium będzie zgodna z postanowieniami Karty NZ, Aktu Końcowego KBWE, Paryskiej Karty Nowej Europy i innymi dokumentami KBWE (art. 3 ust. 3). Ponadto obaj kontrahenci zgodzili się, że będą układać swoje stosunki w dziedzinie wojskowości na podstawie odrębnych umów (art. 5 ust. 4$)^{44}$.

44 Państwa są związane: Umową między Rządem Rzeczypospolitej Polskiej a Rządem Republiki Litewskiej w sprawie utworzenia wspólnej jednostki wojskowej dla utrzymania 


\section{Uwagi końcowe}

Z przeprowadzonej analizy traktatów o przyjaźni i współpracy zawartych przez Polskę z państwami sąsiednimi wynika, że zagadnienia dotyczące bezpieczeństwa zajmują w nich szczególną rangę, na co wskazuje nie tylko forma poszczególnych regulacji traktatowych, ale także strona merytoryczna - treść. Należy jednocześnie podkreślić, że takie ujęcie zagadnień bezpieczeństwa i ich gwarancji we wzajemnych stosunkach z niektórymi państwami nie było procesem łatwym. Dotyczyło to chociażby kwestii zaproponowanych klauzul bezpieczeństwa przez ZSRR, na które Polska się nie zgadzała - przewidywały one m.in. zakaz wstępowania do sojuszy i zawierania porozumień wymierzonych przeciwko jednej ze stron, stacjonowania obcych wojsk na terytorium państw-stron, braku możliwości udostępniania przez Polskę byłych radzieckich baz wojskowych siłom zbrojnym obcych państw, zagwarantowania wojskom radzieckim prawa do swobodnego tranzytu przez terytorium Rzeczypospolitej Polskiej. Ostatecznie jednak w zawartym Traktacie polsko-rosyjskim z 1992 r. udało się wynegocjować odpowiednie klauzule bezpieczeństwa ${ }^{45}$.

W prezentowanych umowach państwa zwróciły uwagę na potrzebę podejmowania działań na rzecz pokoju i bezpieczeństwa w Europie i na świecie. Zawarto $\mathrm{w}$ nich postanowienia dotyczące współpracy na rzecz rozbrojenia w zakresie broni masowej zagłady, a także zwrócono uwagę na znaczenie Traktatu o konwencjonalnych siłach zbrojnych w Europie oraz na zmniejszenie poziomu zbrojeń - tylko dla celów obronnych.

\footnotetext{
i przywracania międzynarodowego pokoju i bezpieczeństwa, sporządzoną w Trokach w dniu 25 czerwca 1997 r. (tekst w: Internetowa Baza Traktatowa MSZ, https:/ / traktaty. msz.gov.pl/ [dostęp: 10.05.2019 r.]); Umową między Rządem Rzeczypospolitej Polskiej a Rządem Republiki Litewskiej dotyczącą współpracy w dziedzinie obronności, sporządzoną w Wilnie dnia 5 lutego 2001 r. (M.P. z 2002 r. Nr 6, poz. 117); Umową między Ministrem Obrony Narodowej Rzeczypospolitej Polskiej a Ministerstwem Obrony Narodowej Republiki Litewskiej o współpracy w dziedzinie obronności, podpisaną w Wilnie dnia 16 czerwca 2010 r. (M.P. z 2018 r. poz. 942).

W postanowieniach dotyczących ochrony środowiska naturalnego użyto sformułowania „bezpieczeństwo ekologiczne”. Szerzej na ten temat zob. W.Sz. Staszewski, Wspótpraca w zakresie ochrony środowiska..., s. 549-550.

45 Szerzej na ten temat zob. M. Menkiszak, Trudne sąsiedztwo: problematyka bezpieczeństwa w stosunkach Polski z ZSRR i Rosja w latach 1989-2000, [w:] R. Kuźniar (red.), Polska polityka bezpieczeństwa 1989-2000, Warszawa 2001, s. 167-169.
} 
W traktatach zawartych przez Polskę z Niemcami, Ukrainą i Białorusią kontrahenci wyrzekli się użycia siły i groźby jej użycia we wzajemnych stosunkach. Z kolei w Traktacie polsko-niemieckim z $1991 \mathrm{r}$. strony zobowiązały się, że nie będą stosowały tego typu instrumentów, w jakikolwiek inny sposób niezgodny z celami i zasadami Karty NZ lub Aktu Końcowego KBWE. Dodano także, że nigdy i w żadnych okolicznościach jako pierwsze nie skierują sił zbrojnych przeciw sobie. Umowy zawarte przez Polskę z Rosją i Litwą przewidują, że kontrahenci powstrzymają się w stosunkach wzajemnych od użycia siły lub groźby ich użycia. Nie znalazło się tego typu postanowienie w traktacie z Czeską i Słowacją Republiką Federacyjną, ale trzeba zwrócić uwagę, co należy też podkreślić, że to jedyna umowa spośród analizowanych, która zawiera innego typu postanowienie, z którego wynika, że w przypadku zbrojnej napaści na jednego z kontrahentów, porozumieją się oni w sprawie możliwości udzielenia napadniętemu pomocy (zgodnie z art. 51 Karty NZ) oraz będą podejmować wysiłki, by konflikt został rozwiązany zgodnie z zasadami, określonymi w Karcie NZ i dokumentach KBWE. Umowy Polski ze wschodnimi sąsiadami zawierają tzw. negatywne klauzule bezpieczeństwa, z których wynika, że w przypadku dokonania agresji na jedną ze stron umowy, druga strona zobowiązuje się nie udzielać agresorowi żadnej pomocy. Tego typu klauzula ze zrozumiałych względów nie została zawarta w Układzie polsko-czechosłowackim z 1991 r. Nie została ujęta także w Traktacie polsko-niemieckim z 1991 r., gdyż uznano, że nie jest ona potrzebna w umowie pomiędzy państwami, które znajdują się w jednym kręgu bezpieczeństwa ${ }^{46}$.

Dodać też należy, że w omawianych umowach zawarto wiele postanowień, regulujących zagadnienia wzajemnych konsultacji, m.in. także wówczas, kiedy jeden z kontrahentów uzna, że powstała sytuacja międzynarodowa, mogąca zagrozić lub naruszyć suwerenność lub inne żywotne interesy bezpieczeństwa.

Podsumowując, można zatem stwierdzić, że w traktatach o przyjaźni i współpracy, zawartych przez Polskę z państwami sąsiednimi stworzone zostały odpowiednie gwarancje dla bezpieczeństwa Rzeczypospolitej Polskiej. Tego stanu rzeczy nie da się przecenić z co najmniej jednego powodu. Otóż, jak na wstępie wskazano, polityka traktatowa wpisuje się in extenso $\mathrm{w}$ politykę zagraniczną każdego państwa. To zaś czyni uprawnionym twierdzenie o konieczności łącznego rozpatrywania obu tych

\footnotetext{
46 Zob. J. Barcz, Polska - Niemcy. Traktat o dobrym sasiedztwie..., s. 29.
} 
kategorii i w ślad za tym, o niecelowości podejmowania przez którekolwiek z państw takich działań, w których realizowana polityka zagraniczna abstrahowałaby od fundamentalnej kwestii bezpieczeństwa państwa jako podmiotu prawa międzynarodowego. Pominięcie kwestii bezpieczeństwa dowodziłoby bowiem fasadowości uprawianej polityki zagranicznej.

Należy też zauważyć, że analizowane traktaty były zawierane na początku lat 90. XX w., kiedy dopiero były zgłaszane polskie aspiracje dotyczące uzyskania członkostwa w Organizacji Traktatu Północnoatlantyckiego (NATO). Warto nadmienić, że formalnie Polska stała się członkiem tej organizacji w 1999 r. ${ }^{47}$, a w jej skład wchodzą obecnie nie tylko Niemcy, ale także i jej niektórzy „nowi sąsiedzi”, a mianowicie: Czechy (od 1999 r.), Litwa (od 2004 r.) i Słowacja (od 2004 r.).

Słowa kluczowe: bezpieczeństwo międzynarodowe, bezpieczeństwo międzynarodowe Polski, gwarancje bezpieczeństwa, polityka zagraniczna Polski, praktyka traktatowa Polski, rozbrojenie, stosunki traktatowe Polski, traktaty o przyjaźni i współpracy, umowy międzynarodowe

\section{Bibliografia}

\section{Źródła}

\section{Umowy międzynarodowe}

Karta Narodów Zjednoczonych, podpisana podczas Konferencji Narodów Zjednoczonych w San Francisco w dniu 26 czerwca 1945 r., Dz. U. z 1947 r. Nr 23, poz. 90 z późn. zm. oraz A. Przyborowska-Klimczak, Prawo międzynarodowe publiczne. Wybór dokumentów, Lublin 2006, s. 9-30.

47 Traktat Północnoatlantycki sporządzony w Waszyngtonie w dniu 4 kwietnia 1949 r., (Dz. U. z 2000 r. Nr 87, poz. 970) został ratyfikowany przez Prezydenta Rzeczypospolitej Polskiej w dniu 26 lutego 1999 r., na podstawie ustawy z dnia 17 lutego 1999 r. o ratyfikacji Traktatu Północnoatlantyckiego, sporządzonego w Waszyngtonie dnia 4 kwietnia 1949 r. (Dz. U. z 1999 r. Nr 13, poz. 111). Dokument ratyfikacyjny Traktatu został złożony w dniu 12 marca 1999 r. Rządowi Stanów Zjednoczonych Ameryki i Traktat wszedł w życie w stosunku do Polski, zgodnie z postanowieniami jego art. 10, w dniu 12 marca $1999 \mathrm{r}$. Zob. Oświadczenie rządowe z dnia 18 sierpnia 2000 r. w sprawie ratyfikacji przez Rzeczpospolitą Polską Traktatu Północnoatlantyckiego, sporządzonego w Waszyngtonie dnia 4 kwietnia 1949 r., Dz. U. z 2000 r. Nr 87, poz. 971. 
Traktat Północnoatlantycki sporządzony w Waszyngtonie dnia 4 kwietnia 1949 r., Dz. U. z 2000 r. Nr 87, poz. 970.

Układ o nierozprzestrzenianiu broni jądrowej, sporządzony w Moskwie, Waszyngtonie i Londynie dnia 1 lipca 1968 r., Dz. U. z 1970 r. Nr 8, poz. 60, zał.

Traktat między Rzecząpospolitą Polską a Republiką Federalną Niemiec o potwierdzeniu istniejącej między nimi granicy, podpisany w Warszawie dnia 14 listopada 1990 r., Dz. U. z 1992 r. Nr 14, poz. 54.

Traktat o konwencjonalnych siłach zbrojnych w Europie, podpisany w Paryżu dnia 19 listopada 1990 r., Dz. U. z 1995 r. Nr 15, poz. 73, zał.

Traktat między Rzecząpospolitą Polską a Republiką Federalną Niemiec o dobrym sąsiedztwie i przyjaznej współpracy, podpisany w Bonn dnia 17 czerwca 1991 r., Dz. U. z 1992 r. Nr 14, poz. 56 oraz A. Przyborowska-Klimczak, W. Staszewski, Stosunki traktatowe Polski z państwami sasiednimi. Wybór dokumentów, Lublin 1998, s. 21-33.

Układ między Rzecząpospolitą Polską a Czeską i Słowacką Republiką Federacyjną o dobrym sąsiedztwie, solidarności i przyjacielskiej współpracy, sporządzony w Krakowie dnia 6 października 1991 r., Dz. U. z 1992 r. Nr 59, poz. 296 oraz R. Podgórzańska, B. Szczepanik (wybór i oprac.), Uregulowania traktatowe Polski w latach 1945-1998, Koszalin 1999, s. 148-156.

Traktat między Rzecząpospolitą Polską a Ukrainą o dobrym sąsiedztwie, przyjaznych stosunkach i współpracy, sporządzony w Warszawie dnia 18 maja 1992 r., Dz. U. z 1993 r. Nr 125, poz. 573 oraz A. Przyborowska-Klimczak, W. Staszewski, Stosunki traktatowe Polski z państwami sąsiednimi. Wybór dokumentów, Lublin 1998, s. 120-126.

Traktat między Rzecząpospolitą Polską a Federacją Rosyjską o przyjaznej i dobrosąsiedzkiej współpracy, sporządzony w Moskwie dnia 22 maja 1992 r., Dz. U. z 1993 r. Nr 61, poz. 291 oraz J. Kukułka, Traktaty sasiedzkie Polski Odrodzonej, Wrocław 1998, s. 226-231.

Traktat między Rzecząpospolitą Polską a Republiką Białoruś o dobrym sąsiedztwie i przyjaznej współpracy, podpisany w Warszawie dnia 23 czerwca 1992 r., Dz. U. z 1993 r. Nr 118, poz. 527 oraz Z. Leszczyński, A. Kosecki (wybór, red. i oprac.), Stosunki międzynarodowe 1989-2000. Wybór tekstów źródtowych i materiatów, Pułtusk 2001, s. 209-214.

Protokół między Rządem Rzeczypospolitej Polskiej a Rządem Republiki Słowackiej dotyczący obowiązywania w stosunkach między Rzecząpospolitą Polską a Republiką Słowacką dwustronnych umów międzynarodowych zawartych między Polską (Rzecząpospolitą Polską, Polską Rzecząpospolitą Ludową) a Czechosłowacją (Republiką Czechosłowacką, Czechosłowacką Republiką Socjalistyczną, Czeską i Słowacką Republiką Federacyjną) w latach 1918-1992, podpisany w Bratysławie w dniu 8 lipca 1993 r., tekst 
w: A. Przyborowska-Klimczak, W. Staszewski, Stosunki traktatowe Polski z państwami sąsiednimi. Wybór dokumentów, Lublin 1998, s. 117-119.

Traktat między Rzecząpospolitą Polską a Republiką Litewską o przyjaznych stosunkach i dobrosąsiedzkiej współpracy, sporządzony w Wilnie dnia 26 kwietnia 1994 r., Dz. U. z 1995 r. Nr 15, poz. 71 oraz A. Przyborowska-Klimczak, W. Staszewski, Stosunki traktatowe Polski z państwami sąsiednimi. Wybór dokumentów, Lublin 1998, s. 196-204.

Protokół między Rządem Rzeczypospolitej Polskiej a Rządem Republiki Czeskiej o sukcesji umów dwustronnych i przeglądzie systemu traktatowego między Rzecząpospolitą Polską i Republiką Czeską, podpisany w Warszawie w dniu 29 marca 1996 r., tekst w: A. Przyborowska-Klimczak, W. Staszewski, Stosunki traktatowe Polski z państwami sąsiednimi. Wybór dokumentów, Lublin 1998, s. $85-87$.

Porozumienie między Ministerstwem Obrony Narodowej Rzeczypospolitej Polskiej a Ministerstwem Obrony Republiki Czeskiej o współpracy w dziedzinie wojskowej, podpisane w Vyszkovie w dniu 13 kwietnia 1996 r., tekst w: Internetowa Baza Traktatowa MSZ, https://traktaty.msz.gov.pl/ [dostęp: 10.05.2019 r.].

Porozumienie między Rządem Rzeczypospolitej Polskiej a Rządem Ukrainy o wzajemnych dostawach uzbrojenia, techniki wojskowej i świadczeniu usług o charakterze wojskowo-technicznym, sporządzone w Kijowie w dniu 10 października 1996 r., tekst w: Internetowa Baza Traktatowa MSZ, https:/ / traktaty.msz.gov.pl/ [dostęp: 10.05.2019 r.].

Umowa między Rządem Rzeczypospolitej Polskiej a Rządem Republiki Litewskiej w sprawie utworzenia wspólnej jednostki wojskowej dla utrzymania i przywracania międzynarodowego pokoju i bezpieczeństwa, sporządzona w Trokach w dniu 25 czerwca 1997 r., tekst w: Internetowa Baza Traktatowa MSZ, https:/ / traktaty.msz.gov.pl/ [dostęp: 10.05.2019 r.].

Porozumienie między Ministerstwem Obrony Narodowej Rzeczypospolitej Polskiej a Ministerstwem Obrony Republiki Czeskiej w sprawie ochrony wojskowych informacji niejawnych, podpisane w Sychrovie w dniu 1 października 1998 r., tekst w: Internetowa Baza Traktatowa MSZ, https:// traktaty.msz.gov.pl/ [dostęp: 10.05.2019 r.].

Umowa między Rządem Rzeczypospolitej Polskiej a Rządem Republiki Federalnej Niemiec o czasowym pobycie członków sił zbrojnych Rzeczypospolitej Polskiej i członków sił zbrojnych Republiki Federalnej Niemiec na terytorium drugiego państwa, sporządzona w Warszawie dnia 23 sierpnia 2000 r., Dz. U. z 2002 r. Nr 206, poz. 1750.

Umowa między Rządem Rzeczypospolitej Polskiej a Rządem Republiki Litewskiej dotycząca współpracy w dziedzinie obronności, sporządzona w Wilnie dnia 5 lutego 2001 r., M.P. z 2002 r. Nr 6, poz. 117. 
Porozumienie między Rządem Rzeczypospolitej Polskiej a Rządem Federacji Rosyjskiej w sprawie współpracy wojskowo-technicznej, podpisane w Moskwie dnia 22 kwietnia 2003 r., Dz. U. z 2004 r. Nr 216, poz. 2199.

Umowa między Rządem Rzeczypospolitej Polskiej a Gabinetem Ministrów Ukrainy o dodatkowych środkach budowy zaufania i bezpieczeństwa, podpisana w Warszawie dnia 16 kwietnia 2004 r., M.P. z 2005 r. Nr 5, poz. 47.

Umowa między Rządem Rzeczypospolitej Polskiej a Rządem Federacji Rosyjskiej dotycząca współpracy przy wwozie do Federacji Rosyjskiej napromieniowanego paliwa jądrowego $\mathrm{z}$ reaktora doświadczalnego, sporządzona w Sopocie w dniu 1 września 2009 r., tekst w: Internetowa Baza Traktatowa MSZ, https://traktaty.msz.gov.pl/ [dostęp: 10.05.2019 r.].

Umowa między Ministrem Obrony Narodowej Rzeczypospolitej Polskiej a Ministerstwem Obrony Narodowej Republiki Litewskiej o współpracy w dziedzinie obronności, podpisana w Wilnie dnia 16 czerwca 2010 r., M.P. z 2018 r. poz. 942.

Umowa Ramowa między Rządem Rzeczypospolitej Polskiej a Rządem Republiki Federalnej Niemiec o współpracy obronnej, podpisana w Warszawie dnia 21 czerwca 2011 r., M.P. z 2018 r. poz. 961.

Umowa między Rządem Rzeczypospolitej Polskiej a Rządem Republiki Słowackiej o współpracy obronnej, podpisana w Bratysławie dnia 16 maja 2014 r., M.P. z 2017 r. poz. 240.

Protokół między Ministrem Obrony Narodowej Rzeczypospolitej Polskiej a Ministerstwem Obrony Ukrainy o nieodpłatnym przekazaniu wybranych składników mienia wojskowego, podpisany w Warszawie dnia 14 sierpnia 2014 r., M.P. z 2015 r. poz. 581.

Protokół między Rządem Rzeczypospolitej Polskiej a Gabinetem Ministrów Ukrainy $\mathrm{w}$ sprawie wprowadzenia zmian do Porozumienia między Rządem Rzeczypospolitej Polskiej a Rządem Ukrainy o wzajemnych dostawach uzbrojenia, techniki wojskowej i świadczenia usług o charakterze wojskowo-technicznym, sporządzonego w Kijowie dnia 10 października 1996 r., sporządzony w Warszawie w dniu 9 lipca 2016 r., tekst w: Internetowa Baza Traktatowa MSZ, https:/ / traktaty.msz.gov.pl/ [dostęp: 10.05.2019 r.].

Umowa Ogólna między Rządem Rzeczypospolitej Polskiej a Gabinetem Ministrów Ukrainy w sprawie wzajemnej współpracy w dziedzinie obronności, sporządzona w Warszawie dnia 2 grudnia 2016 r., M.P. z 2019 r. poz. 50.

\section{Inne dokumenty międzynarodowe}

Akt Końcowy Konferencji Bezpieczeństwa i Współpracy w Europie, przyjęty w Helsinkach w dniu 1 sierpnia 1975 r., tekst w: A.D. Rotfeld (red. i wprowadzenie), Z Lachowski, A.D. Rotfeld (wybór i oprac.), Od Helsinek do Madrytu. Dokumenty Konferencji Bezpieczeństwa i Wspótpracy w Europie 1973- 1983, Warszawa 1983, s. 110-203. 
Paryska Karta Nowej Europy, przyjęta w Paryżu w dniu 21 listopada 1990 r., tekst w: A. Przyborowska-Klimczak, E. Skrzydło-Tefelska (oprac.), Dokumenty europejskie, t. 2, Lublin 1999, s. 78-91.

\section{Akty prawa polskiego}

Ustawa z dnia 17 lutego 1999 r. o ratyfikacji Traktatu Północnoatlantyckiego, sporządzonego w Waszyngtonie dnia 4 kwietnia 1949 r., Dz. U. z 1999 r. Nr 13, poz. 111.

\section{Inne dokumenty}

Oświadczenie rządowe z dnia 18 sierpnia 2000 r. w sprawie ratyfikacji przez Rzeczpospolitą Polską Traktatu Północnoatlantyckiego, sporządzonego w Waszyngtonie dnia 4 kwietnia 1949 r., Dz. U. z 2000 r. Nr 87, poz. 971.

\section{Literatura}

Banaszkiewicz A., Umowy międzynarodowe jako środek osiagania celów w polityce zagranicznej państwa, [w:] M.S. Wolański (red.), Uwarunkowania i kierunki polskiej polityki zagranicznej w pierwszej dekadzie XXI wieku, Wrocław 2004.

Banaszkiewicz A., Umowy międzynarodowe zawarte przez Polskę z państwami europejskimi w latach 1989-2000 jako środek realizacji polskiej polityki zagranicznej, Łódź 2007.

Barcz J., Podstawy polityczne i prawne stosunków Polski ze zjednoczonymi Niemcami, [w:] B. Wizimirska (red.), Rocznik Polskiej Polityki Zagranicznej 1991, Warszawa 1993.

Barcz J., Polska - Niemcy. Traktat o dobrym sąsiedztwie i przyjaznej wspótpracy, „Panstwo i Prawo" 1991, z. 9.

Brodowski L., Stosunki z Litwa, [w:] B. Wizimirska (red.), Rocznik Polskiej Polityki Zagranicznej 1995, Warszawa 1995.

Cesarz Z., Kwestia zbrojeń i rozbrojenia, [w:] Z. Cesarz, E. Stadtmüller, Problemy polityczne wspótczesnego świata, Wrocław 2000.

Cesarz Z., Problemy rozbrojenia i ograniczenia zbrojeń, [w:] T. Łoś-Nowak (red.), Wspótczesne stosunki międzynarodowe, Wrocław 1995.

Chajewski A., Okoliczności wynegocjowania i podpisania traktatu między Rzeczapospolita Polska a Republikg Litewską o przyjaznych stosunkach i dobrosasiedzkiej wspótpracy, "Studium Vilnense A" 2017, t. 14.

Gadkowski T., Międzynarodowa kontrola nierozprzestrzeniania broni jądrowej, "Ruch Prawniczy, Ekonomiczny i Socjologiczny" 1983, z. 4.

Gil K., T. Jasułowski, Der Vertrag und die Folgen: Deutschland und Polen als Nachbarn, "Osteuropa” 2011, t. 61, nr 5/6. 
Jasica R., Polish-German Treaties of 1990 and 1991 on the Confirmation of Their Mutual Border and on Good Neighborliness and Friendly Co-operation, „Polish Yearbook of International Law" 1991, nr 1/2.

Kaczmarski M., Problematyka zbrojeń i rozbrojenia, [w:] R. Zięba (red.), Bezpieczeństwo międzynarodowe po zimnej wojnie, Warszawa 2008.

Kapuśniak T., Struktura reżimu o rozbrojeniu konwencjonalnym w Europie, „Annales Universitatis Mariae Curie-Skłodowska" Sectio K Politologia 2005, t. 12.

Kochnowski R., Geneza rozpadu Czechostowacji, „Studia Politicae Universitatis Silesiensis" 2005, t. 1.

Kopeć R., Traktat o nierozprzestrzenianiu broni nuklearnej jako prawnomiędzynarodowy reżim zapobiegania proliferacji, „Annales Universitatis Paedagogicae Cracoviensis. Studia de Securitate et Educatione Civili" 2015, nr 5.

Kukułka J., Traktaty sasiedzkie Polski Odrodzonej, Wrocław 1998.

Kuźniar R., Polityka bezpieczeństwa w polskiej polityce zagranicznej, [w:] R. Kuźniar (red.), Polska polityka bezpieczeństwa 1989-2000, Warszawa 2001.

Leszczyński Z., A. Koseski (red.), Stosunki międzynarodowe 1989-2000. Wybór tekstów źródtowych i materiatów, Pułtusk 2001.

Menkiszak M., Trudne sąsiedztwo: problematyka bezpieczeństwa w stosunkach Polski z ZSRR i Rosja w latach 1989-2000, [w:] R. Kuźniar (red.), Polska polityka bezpieczeństwa 1989-2000, Warszawa 2001.

Mróz M., Traktat o konwencjonalnych siłach zbrojnych w Europie (CFE) (wersja poprawiona, uzupetniona i zaktualizowana), „Raport Biura Studiów i Analiz Kancelarii Sejmu" 2015, nr 74A.

Noworyta E., Różne oblicza polskiej racji stanu, Łódź-Warszawa 2010.

Pacuła P., Wspótpraca obronna w regionie Morza Battyckiego. Stan obecny i perspektywy, „Bezpieczeństwo Narodowe” 2013, t. 26, nr 2.

Podgórzańska R., B. Szczepanik (oprac.), Uregulowania traktatowe Polski w latach 1945-1998: teksty wybranych dwustronnych umów politycznych zawartych przez Polskę z niektórymi krajami europejskimi, Koszalin 1999.

Prystrom J., Problem bezpieczeństwa w polityce zagranicznej Polski, [w:] B. Wizimirska (red.), Rocznik Polskiej Polityki Zagranicznej 1991, Warszawa1993.

Przyborowska-Klimczak A., E. Skrzydło-Tefelska (oprac.), Dokumenty europejskie, t. 2, Lublin 1999.

Przyborowska-Klimczak A., Prawo międzynarodowe publiczne. Wybór dokumentów, Lublin 2006.

Przyborowska-Klimczak A., W. Staszewski, Stosunki traktatowe Polski z państwami sąsiednimi. Wybór dokumentów, Lublin 1998.

Przyborowska-Klimczak A., W.Sz. Staszewski (oprac.), Traktaty o przyjaźni i w wspótpracy zawarte przez Polskę. Wybór dokumentów, Lublin 2005. 
Rotfeld A.D. (red. i wprowadzenie), Z Lachowski, A.D. Rotfeld (wybór i oprac.), Od Helsinek do Madrytu. Dokumenty Konferencji Bezpieczeństwa i Wspótpracy w Europie 1973-1983, Warszawa 1983.

Rotfeld A.D., Polska w niepewnym świecie, Warszawa 2006.

Skubiszewski K., Problemy polityki zagranicznej u progu roku 1991 - wystapienie ministra spraw zagranicznych RP w Sejmie, Warszawa, 14 lutego 1991 r., "Zbiór Dokumentów" 1992, z. 1.

Skubiszewski K., Racja stanu Rzeczypospolitej Polskiej, [w:] K. Skubiszewski, Polityka zagraniczna i odzyskanie niepodległości. Przemówienia, oświadczenia, wywiady 1989-1993, Warszawa 1997.

Staszewski W.Sz., Wspótpraca w zakresie ochrony środowiska w traktatach o przyjaźni i wspótpracy zawartych przez Polskę po 1989 r., [w:] B. Mikołajczyk, J. Nowakowska-Małusecka (red.), Prawo międzynarodowe, europejskie i krajowe - granice i wspólne obszary. Księga jubileuszowa dedykowana Profesor Genowefie Grabowskiej, Katowice 2009.

Strulak T., Działania na rzecz rozbrojenia i kontroli zbrojeń, [w:] J. Symonides (red.), Organizacja Narodów Zjednoczonych. Bilans i perspektywy, Warszawa 2006.

Szafarz R., Stosunki traktatowe Rzeczypospolitej Polskiej. Nowa jakość w latach 1989-2000, „Studia Prawnicze” 2003, z. 2.

Szayna T.S., Rozpad Czecho-Słowacji (kilka uwag o jego konsekwencjach), "Sprawy Międzynarodowe" 1993, z. 1.

Śmigerska-Belczak I., Wspótpraca w regionie Morza Battyckiego - Rada Państw Morza Battyckiego, „Kwartalnik Kolegium Ekonomiczno-Społecznego. Studia i Prace" 2012, nr 1.

Tabor M., Porozumienia w sprawie kontroli zbrojeń i rozbrojenia, [w:] R. Kuźniar i in., Bezpieczeństwo międzynarodowe, Warszawa 2012.

Zenderowski R., Przyczyny rozpadu Czecho-Stowacji, "Sprawy Międzynarodowe” 2005, z. 3.

Żyła M., Między Wschodem a Zachodem. Problemy bezpieczeństwa militarnego Ukrainy, "Ante Portas - Studia nad Bezpieczeństwem” 2016, nr 1.

Żyła M., Polsko-ukraińska współpraca wojskowa w polityce bezpieczeństwa Polski, Warszawa 2016. 


\section{INTERNATIONAL SECURITY IN THE TREATIES OF FRIENDSHIP AND COOPERATION MADE BY POLAND WITH THE NEIGHBOURING STATES}

\section{Sum mary}

The events at the turn of 1989/1990 that influenced the transformations in Poland and other countries of the Eastern and Central Europe caused the security issues and security assurance guarantees to become the fundamental elements of the Polish national interest and the main objective of the implemented foreign policy. A process of building new treaties and connections has begun. This paper analyses the Treaties of Friendship and Cooperation made by Poland that have a special role in the states' treaties policy. The subject of the paper is limited to the treaties with the neighbouring states since, after the changes in the closest surroundings, Poland obtained new neighbours. The purpose of this article is to answer questions if, in the Treaties of Friendship and Cooperation made by Poland after 1989, there were any security issues that reflected the common states' interest and whether those provisions were given the proper rank, and, at the same time, if there were any guarantees for Poland's security.

Key words: international security, international security of Poland, security guarantees, Polish foreign policy, Polish treaties practice, disarmament, Polish treaties relations, Treaties of Friendship and Cooperation, international agreements

\section{МЕЖДУНАРОДНАЯ БЕЗОПАСНОСТЬ В ДОГОВОРАХ О ДРУЖБЕ И СОТРУДНИЧЕСТВЕ, ЗАКЛЮЧЕННЫХ ПОЛЬШЕЙ С СОСЕДНИМИ СТРАНАМИ}

\section{Резюме}

События на рубеже 1989-1990 годов, которые повлияли на преобразования в Польше и других странах Центральной и Восточной Европы, привели к тому, что вопросы безопасности и гарантии ее обеспечения стали основным элементом польских государственных интересов и главной целью осуществляемой внешней политики. Начался процесс построения новых договорных отношений. В данной статье анализируются договоры о дружбе и сотрудничестве, заключенные Польшей, которые играют особую роль в договорных отношениях государств. Предметная сфера анализа была ограничена до договоров, заключенных с соседними странами, с учетом факта изменений в непосредственном окружении Польши, которая приобрела новых соседей на своих границах. Цель исследования состоит в том, 
чтобы ответить на исследовательский вопрос: включены ли в договоры о дружбе и сотрудничестве, заключенные Польшей после 1989 года с соседними странами, положения, касающиеся международной безопасности, которые являются проявлением общего интереса и сотрудничества государств в этом отношении, и был ли присвоен этим нормам соответствующий ранг и, следовательно, были ли найдены соответствующие гарантии для обеспечения безопасности Республики Польша.

Ключевые слова: международная безопасность, международная безопасность Польши, гарантии безопасности, внешняя политика Польши, договорная практика Польши, разоружение, договорные отношения Польши, договоры о дружбе и сотрудничестве, международные соглашения 
